\title{
In-cloud processes of methacrolein under simulated conditions - Part 3: Hygroscopic and volatility properties of the formed secondary organic aerosol
}

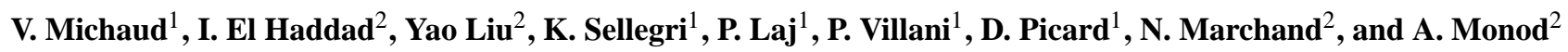 \\ ${ }^{1}$ LaMP, CNRS-Université Blaise Pascal, 63117 Aubière Cedex, France \\ ${ }^{2}$ LCP, CNRS-UMR 6264, Université de Provence, 3 Place Victor Hugo, case 29, 13003 Marseille, France
}

Received: 23 January 2009 - Published in Atmos. Chem. Phys. Discuss.: 10 March 2009

Revised: 26 June 2009 - Accepted: 1 July 2009 - Published: 28 July 2009

\begin{abstract}
The hygroscopic and volatility properties of secondary organic aerosol (SOA) produced from the nebulization of solutions after aqueous phase photooxidation of methacrolein was experimentally studied in a laboratory, using a Volatility-Hygroscopicity Tandem DMA (VHTDMA). The obtained SOA were $80 \% 100^{\circ} \mathrm{C}$-volatile after $5 \mathrm{~h}$ of reaction and only $20 \% 100^{\circ} \mathrm{C}$-volatile after $22 \mathrm{~h}$ of reaction. The Hygroscopic Growth Factor (HGF) of the SOA produced from the nebulization of solutions after aqueous-phase photooxidation of methacrolein is $1.34-1.43$, which is significantly higher than the HGF of SOA formed by gas-phase photooxidation of terpenes, usually found almost hydrophobic. These hygroscopic properties were confirmed for SOA formed by the nebulization of the same solutions where $\mathrm{NaCl}$ was added. The hygroscopic properties of the cloud droplet residuals decrease with the reaction time, in parallel with the formation of more refractory compounds. This decrease was mainly attributed to the $250^{\circ} \mathrm{C}$-refractive fraction (presumably representative of the highest molecular weight compounds), which evolved from moderately hygroscopic (HGF of 1.52) to less hygroscopic (HGF of 1.36). Oligomerization is suggested as a process responsible for the decrease of both volatility and hygroscopicity with time. The $\mathrm{NaCl}$ seeded experiments enabled us to show that $19 \pm 4 \mathrm{mg} \mathrm{L}^{-1}$ of SOA was produced after $9.5 \mathrm{~h}$ of reaction and $41 \pm 9 \mathrm{mg} \mathrm{L}^{-1}$ after $22 \mathrm{~h}$ of in-cloud reaction. Because more and more SOA is formed as the reaction time increases, our results show that the reaction products formed during the aqueous-phase
\end{abstract}

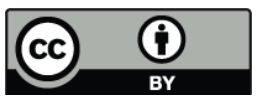

Correspondence to: K. Sellegri (k.sellegri@opgc.univ-bpclermont.fr)
$\mathrm{OH}$-oxidation of methacrolein may play a major role in the properties of residual particles upon the droplet's evaporation. Therefore, the specific physical properties of SOA produced during cloud processes should be taken into account for a global estimation of SOA and their atmospheric impacts.

\section{Introduction}

Aerosol particles play an important but still poorlyunderstood role in the atmosphere. Indeed, atmospheric aerosol particles affect human health and the earth's radiation balance in various ways (IPCC, 2007). First, aerosol particles absorb and scatter solar radiation (direct effect), and second, aerosols are activated to cloud droplets (indirect effect). The direct and indirect effects are both dependent on the size distribution and chemical composition which drive optical and hygroscopic properties of the aerosol particles. The capacity of water to condense onto aerosol particles influences heterogeneous reactions (Ravishankara, 1997), light extinction and visibility (Dick et al., 2000), whereby aerosol water is most relevant for the direct radiative forcing of the Earth's climate (Pilinis et al., 1995).

The particles composition varies with size, time, and location, reflecting their diverse origins and atmospheric processing. The hygroscopic properties of main inorganic salts present in atmospheric particles are well known (Ansari et al., 1999; Colberg et al., 2003; Kreidenweis et al., 2005). Among all the organic compounds identified in the atmospheric aerosol (Decesari et al., 2000; Shimmo et al., 2004; Putaud et al., 2004), the hygroscopic properties of more and

Published by Copernicus Publications on behalf of the European Geosciences Union. 
more known organic mixtures have been studied (Bilde et al., 2004; Chan et al., 2003; Koehler et al., 2006). Scarcer are the studies of hygroscopic changes with aerosol ageing (Kanakidou et al., 2005; Vesna et al., 2008). Hydrophobic particles such as combustion aerosols are expected to gain hygroscopicity when ageing (Swietlicki et al., 2008) while hygroscopic salts were observed to lose hygroscopicity when ageing (Sellegri et al., 2008). Thus, the resulting aged ambient aerosols are often moderately hygroscopic with Hygroscopic Growth Factor (HGF) between 1.3 and 1.5 when away from the sources (Mc Figgans et al., 2006; Swietlicki et al., 2008).

The Volatility Hygroscopicity Tandem DMA (VHTDMA) technique (Villani et al., 2008; Johnson et al., 2005) has been recently used to investigate the effect of ageing on the hygroscopic properties of aerosol by studying the change in HGF due to the $90^{\circ} \mathrm{C}$ volatile fraction of aerosol (Villani et al., 2009). The technique has shown that the $90^{\circ} \mathrm{C}$ volatile fraction of the marine aerosol present in the accumulation mode slightly decreases its hygroscopicity compared to pure sea salt, indicating that a chemical ageing takes place on marine aerosols (Sellegri et al., 2008). Photooxidation of organic compounds in the gas phase may lead to secondary organic aerosols (SOA) which experience significant chemical changes while ageing, which can be tracked by the study of their volatility properties. For instance, photooxidation of trimethylbenzenes in a smog chamber show that a substantial fraction of the organic aerosol mass is composed of oligomers, which, after ageing for more than $20 \mathrm{~h}$, result in a lower volatility SOA (Kalberer et al., 2004). The processes responsible for hygroscopic changes through ageing can be due to the condensation of gas phase compounds, heterogeneous reactions at the aerosol surface, or in-cloud reactions. The role of water in the atmospheric oxidation processes during ageing has been shown to be crucial (Vesna et al., 2008; Warren et al., 2009; Perri et al., 2009). The effects of ageing on aerosol properties through in-cloud reactions, though, have scarcely been addressed. Up until now, the modification of the inorganic fraction has been investigated mainly in modeling studies (Wurzler et al., 2000) and scarcely experimentally (Levin et al., 1996). In natural clouds, cloud processing has indirectly been shown to increase the hygroscopic properties of aerosol particles (Crumeyrolle et al., 2008). However, the aerosol physical properties (hygroscopicity and volatility) change due to aqueous-phase photooxidation has never, to our knowledge, directly been quantified with identified compounds.

Methacrolein is a major gas phase reaction product of isoprene (Lee et al., 2005) that can be widely found in the gas phase and in cloud and fog waters (van Pinxteren et al., 2005). Hence, it's study can be valuable as an example of terpene oxidation product that can be correlated with other SOA ageing studies in El Haddad et al. (2009), we confirm that significant amounts of SOA are formed by the nebulization of solutions after aqueous-phase photooxidation of methacrolein, as already shown by Chen et al. (2008). The aim of this study is to investigate the hygroscopic and volatility properties of the SOA formed by the nebulization of solutions after aqueous-phase photooxidation of methacrolein, and evaluate the impact that such a simulated cloud processing may have when a hygroscopically active salt $(\mathrm{NaCl})$ is present in the droplet solution.

\section{Methods}

As described in Liu et al. (2009) and El Haddad et al. (2009), SOA produced from the nebulization of solutions after aqueous-phase photooxidation of methacrolein at $25^{\circ} \mathrm{C}$, was studied at different reaction times. Briefly, $\mathrm{OH}$-oxidation of methacrolein was studied in a $450 \mathrm{~mL}$ Pyrex thermostated reactor, illuminated by a Xenon arc lamp. $\mathrm{OH}$ radicals were obtained from the irradiation of $0.4 \mathrm{M} \mathrm{H}_{2} \mathrm{O}_{2}$. For further details, the reader is referred to Liu et al. (2009) and El Haddad et al. (2009). The experimental setup used for the aerosol generation experiments is presented in Fig. 1.

Liquid samples taken from the photoreactor (during the $\mathrm{OH}$-oxidation of methacrolein) at specific reaction times $(0 \mathrm{~h}, 5 \mathrm{~h}, 9.5 \mathrm{~h}, 14 \mathrm{~h}$ and $22 \mathrm{~h})$ were nebulized at a flow rate of 4.2 $\mathrm{L} \mathrm{min}^{-1}$, with a TSI 3079 atomizer, at room temperature (constant $20^{\circ} \mathrm{C}$ ). Then, the aerosol flow was dried by mixing with pure dry air at a flow rate of $5 \mathrm{~L} \mathrm{~min}^{-1}$ and passing through a silica gel diffusion dryer. After drying, the aerosol was delivered into a $200 \mathrm{~L}$ Teflon (PTFE) mixing chamber. At these operating conditions, the average residence time of the aerosol in the whole setup was about $20 \mathrm{~min}$.

Two sets of aerosol generation and characterisation experiments were carried out. In the first set, the liquid samples, taken at different aqueous phase reaction times, were nebulized. The resulting SOA is called "Pure SOA" in the following. In the second set, sodium chloride $\left(100 \mathrm{mg} \mathrm{L}^{-1}\right)$ was added to the same samples prior to nebulization. The resulting aerosol is called "SOA+NaCl" in the following. $\mathrm{NaCl}$ was added to simulate the inorganic fraction of the aerosol. For comparison purposes, a solution of $\mathrm{NaCl}\left(100 \mathrm{mg} \mathrm{L}^{-1}\right)$ diluted in pure water was nebulized following the same procedure. Before each nebulization experiment, the $200 \mathrm{~L}$ mixing chamber was flushed for about $2 \mathrm{~h}$ ( $\sim 6$ times) with synthetic air, and aerosol blanks were controlled by Scanning Mobility Particle Sizer (SMPS) measurements prior to each new experiment. For all experiments, the aerosols obtained were characterized in terms of size distribution, hygroscopicity and volatility.

The size distribution of the generated aerosol was monitored using a SMPS connected to the mixing chamber (Fig. 1). The SMPS is composed of a Long-column Differential Mobility Analyzer (L-DMA, GRIMM Inc.; France) and a Condensation Particle Counter (CPC, model 5.403, GRIMM Inc.; France). The DMA aerosol and sheath operating flow rates were 0.3 and $3 \mathrm{~L} \mathrm{~min}^{-1}$, respectively. 


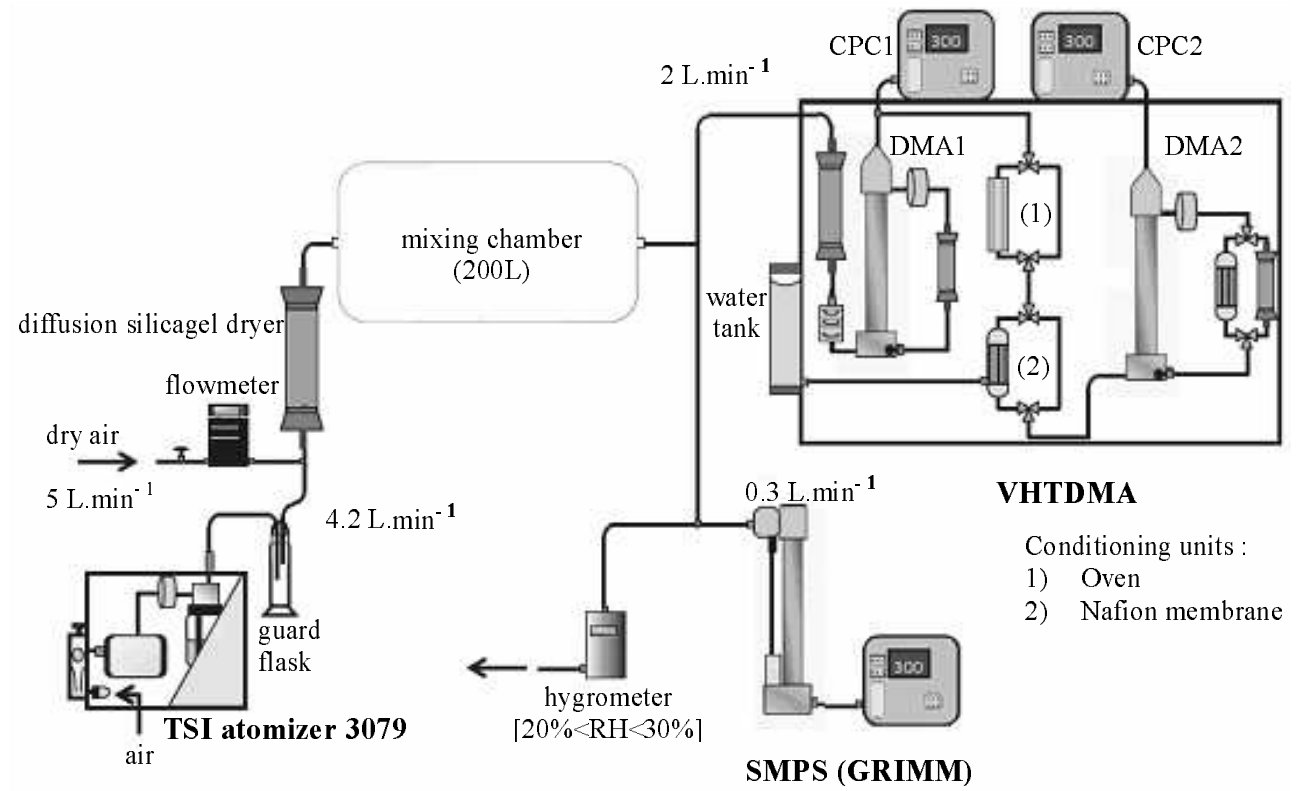

Fig. 1. Scheme of the aerosol generation and characterization experimental setup.

The aerosol hygroscopic growth measurements were conducted at subsaturation using a Volatility-Hygroscopicity Tandem DMA (VHT-DMA). This instrument consists mainly of two tandem DMA-CPCs (TSI), separated by a conditioning unit composed of an oven and a humidification device in series. The measurements were performed first by passing the aerosol from the chamber through a silica gel dryer (at a flow rate of $2 \mathrm{~L} \mathrm{~min}^{-1}$ ) to remove the aerosol remaining bound water, at low $\mathrm{RH}(<15 \%)$. The aerosol was then classified at a constant voltage in the first DMA to a specified diameter $\left(\mathrm{Dp}_{\mathrm{dry}}\right)$ in the size range of the chamber aerosol. The mono-disperse particles from the classifying DMA were then brought to a specified relative humidity (usually $90 \%$ ) by the way of the humidification device (H-scan), or to a specific temperature in the oven ( $\mathrm{V}$-scans) or to a specific temperature and humidity successively (VHscans). The humidification system was composed of a semipermeable membrane condenser (Nafion). It was refrigerated together with the second DMA to achieve higher and more stable RH values. The residence time of the particles in the humid environment was $2 \mathrm{~s}$. The new aerosol size distribution $\left(\mathrm{Dp}_{\mathrm{wet}}\right)$ obtained after the water uptake, or after volatilisation, or the combination of the two were measured by the second DMA-CPC operating in scanning mode. The hygroscopic growth factor (HGF) is defined by Eq. (1).

$\mathrm{HGF}=\frac{\mathrm{D} \mathrm{p}_{\mathrm{wet}}}{\mathrm{D} \mathrm{p}_{\mathrm{dry}}}$

Where $D p_{w e t}$ is the humidified particles diameter, and D $p_{\text {dry }}$ the dry classified particles diameter. Chemical reactions at the aerosol surface, which might be promoted by the water vapour in the humidified sections, are regarded as negligible compared to the liquid-phase chemical reactions which occurred previously over several hours and irradiated conditions.

The Volatility "growth" factor (VGF) can be derived from the Volatility scan. It is the relative size change of a particle due to thermal conditioning, at a constant RH of $10 \%$. For a given thermo-desorbing temperature $T^{\circ}$, it is calculated as the ratio between the particle diameter $\left(D_{p}^{10, T^{\circ}}\right)$ at $T^{\circ}$ and the particle diameter at $\mathrm{RH}=10 \%$ and ambient temperature, here $20^{\circ} \mathrm{C}\left(D_{p}^{10, T^{\circ} \mathrm{amb}}\right)$ (Eq. 2).

$\mathrm{VGF}=\frac{D_{p}^{10, T^{\circ}}}{D_{p}^{10, T^{\circ} \mathrm{amb}}}$

The residual volumic fraction (RVF) is the ratio between the particles volume after and before volatilization. It is derived from the VGF according to Eq. (3).

$\mathrm{RVF}=\left(\frac{D_{p}^{10, T^{\circ}}}{D_{p}^{10, T^{\circ} \mathrm{amb}}}\right)^{3}=\mathrm{VGF}^{3}$

For a thermo-desorbing temperature ranging from ambient temperature to $300^{\circ} \mathrm{C}$, the resulting residence time in the oven heating path $(30 \mathrm{~cm})$ was $1 \mathrm{~s}$.

The Volatility-Hygroscopic growth factor (VHGF) is the hygroscopic growth of a thermally processed particle (Eq. 4):

$\mathrm{VHGF}=\frac{D_{p}^{90, T^{\circ}}}{D_{p}^{10, T^{\circ}}}$

Where $D_{p}^{90, T^{\circ}}$ is the particle diameter at $\mathrm{RH}=90 \%$ and $T^{\circ}>T^{\circ}$ amb. The VHGF is therefore calculated considering the "new" diameter resulting from thermo-desorption. 
Table 1. Stability of relative humidity $(\mathrm{RH})$ and temperature $\left(T^{\circ}\right)$ measured in the system. Means and standard deviations were calculated independently for each experiment.

\begin{tabular}{|c|c|c|c|c|c|}
\hline \multicolumn{2}{|c|}{ Diameter (Dp0) } & \multicolumn{4}{|c|}{$40 \mathrm{~nm}$} \\
\hline \multicolumn{2}{|l|}{ Settings } & HTDMA & VTDMA & \multicolumn{2}{|c|}{ VHTDMA } \\
\hline $\begin{array}{l}\text { Paramete } \\
\text { controlle }\end{array}$ & & $\mathrm{RH}(\%)$ & $T^{\circ}\left({ }^{\circ} \mathrm{C}\right)$ & RH (\%) & $T^{\circ}\left({ }^{\circ} \mathrm{C}\right)$ \\
\hline \multirow{4}{*}{$\begin{array}{l}\text { Time } \\
\text { reaction }\end{array}$} & $5 \mathrm{~h}$ & $89.7 \pm 0.4$ & $249.5 \pm 0.3$ & $89.6 \pm 0.4$ & $248.7 \pm 0.6$ \\
\hline & $9.5 \mathrm{~h}$ & $89.9 \pm 0.2$ & $247.6 \pm 0.4$ & $90.0 \pm 0.5$ & $247.8 \pm 0.5$ \\
\hline & $14 \mathrm{~h}$ & $89.3 \pm 0.7$ & $247.6 \pm 0.3$ & $89.8 \pm 0.1$ & $247.0 \pm 0.3$ \\
\hline & $22 \mathrm{~h}$ & $89.5 \pm 0.1$ & $249.8 \pm 0.3$ & $89.6 \pm 0.4$ & $250.2 \pm 0.5$ \\
\hline
\end{tabular}

The humidity in the system was piloted using a CEM (Controlled Evaporation Mixing) unit, creating a saturated air flow, and a system of Nafion tubes. The temperature in the oven was controlled by software and a thermocouple. Humidity and temperature were measured by RH-T sensors (Model Rotronic, HygroClip 05). The reader is referred to Villani et al. (2008) for a full description of the instrument.

Regarding its hygroscopic growth measurement performances, the HTDMA was intercompared with six other European HTDMA in the frame of the EUSAAR project (http: //www.eusaar.net), and performed well with less than $2.5 \%$ deviation to the theoretical deliquescence $\mathrm{RH}$ of ammonium sulphate (Duplissy et al., 2008). The volatility conditioning unit behaviour was modeled to evaluate its performances, and further tested with standard aerosol particles (Villani et al., 2006).

During the SOA experiments presented here, two different aerosol sizes were studied, both belonging to the same mode produced by the nebulization device, as checked on the SMPS size distributions. Dry scans $(\mathrm{RH}<20 \%, T=$ ambient $)$ were performed regularly to track the relationship between the selected aerosol diameter in DMA1 and the particle diameter detected in DMA2. The uncertainty on HGF determination is mainly linked to the precision and stability of the RH sensors.

The average and standard deviations on the humidifying device $\mathrm{RH}$ and oven $T^{\circ}$ during the experiments are reported in Table 1. The relative humidity is homogeneous among the different experiments (the average values vary between 89.3 and $90.0 \%$ ) and stable within a given experiment (standard deviation $\leq 0.7 \%$ ). According to Duplissy et al. (2008), a RH variability lower than $2 \%$ is required on a given scan to validate the HGF measurements. In our case, the uncertainty associated with our RH variability (less than $0.7 \%$ ) would be, as an example for a $50 \mathrm{~nm}$ ammonium sulfate particle, of \pm 0.025 on the HGF. The oven temperature was also relatively homogeneous $\left(247.0^{\circ} \mathrm{C}\right.$ to $250.2^{\circ} \mathrm{C}$ ) and stable (standard deviation $\leq 0.6^{\circ} \mathrm{C}$ ) (Table 1). In terms of precision, the RH sensors were corrected by using $\mathrm{NaCl}$ as a calibration salt.
For each experiment, an average of the scans realized under specific conditions (ambient dry, VTDMA, VHTDMA, HTDMA) were calculated. Each average hygroscopic growth distribution was then fitted using a Gaussian fit algorithm.

\section{Results}

The chemical analysis of the aqueous phase composition denoted the formation of high molecular weight multifunctional products containing hydroxyl, carbonyl and carboxylic acid moieties, and some of them can be assimilated to oligomers (Liu et al., 2009; El Haddad et al., 2009). The ability of these compounds to produce SOA upon water droplets evaporation, was experimentally examined. We hypothesise that the difference in temperatures between the liquid samples in which chemical analysis were performed $\left(25^{\circ} \mathrm{C}\right)$ and the liquid samples which were nebulized $\left(20^{\circ} \mathrm{C}\right)$ do not imply additional chemical changes of the solution. This hypothesis is strengthened by the fact that no chemical reaction is observed as soon as light is turned off (Liu et al., 2009). The results clearly showed a significant production of SOA. A clear evolution of the particle size, number and mass concentration with the reaction time was obtained: an increase of the aerosol mass from $0.03 \mu \mathrm{g} \mathrm{m}^{-3}$ to $27.8 \mu \mathrm{g} \mathrm{m}^{-3}$, within $22 \mathrm{~h}$ of reaction was observed. The evaluated SOA yield ranged from 2 to $12 \%$ (El Haddad et al., 2009). It is not realistic that the same particle experiences more than $9.5 \mathrm{~h}$ under light conditions in a cloud droplet. However, we expect that successive cloud processes would have the same effect than our experiments performed during $22 \mathrm{~h}$ of photooxidation.

\subsection{Pure SOA experiments}

\subsubsection{Volatility studies}

In Table 2, the Residual Volumic Fractions (RVF) were calculated at different temperatures for SOA particles of 40 and $50 \mathrm{~nm}$ formed from the nebulization of aqueous solutions after $\mathrm{OH}$-oxidation of methacrolein during different reaction 
Table 2. Residual Volumic Fraction (RVF) of SOA formed at different reaction times, after heating in VTDMA at 100,180 and $250^{\circ} \mathrm{C}$. The diameter of the incident particles (selected in the first DMA) is 40 or $50 \mathrm{~nm}$. The values of RVF are the average of two measurements.

\begin{tabular}{lrrrrrrr}
\hline \multicolumn{2}{l}{ Diameter $\left(\mathrm{Dp}_{0}\right)$} & \multicolumn{3}{c}{$40 \mathrm{~nm}$} & & $50 \mathrm{~nm}$ \\
\hline \multicolumn{2}{l}{ Temperature $\left({ }^{\circ} \mathrm{C}\right)$} & $100^{\circ} \mathrm{C}$ & $180^{\circ} \mathrm{C}$ & $250{ }^{\circ} \mathrm{C}$ & $100^{\circ} \mathrm{C}$ & $180{ }^{\circ} \mathrm{C}$ & $250^{\circ} \mathrm{C}$ \\
\hline \multirow{4}{*}{ Time } & $5 \mathrm{~h}$ & $34 \%$ & $31 \%$ & $16 \%$ & $34 \%$ & $31 \%$ & $16 \%$ \\
reaction & $9.5 \mathrm{~h}$ & $19 \%$ & $9 \%$ & $8 \%$ & $23 \%$ & $9 \%$ & $8 \%$ \\
& $22 \mathrm{~h}$ & $85 \%$ & $56 \%$ & $44 \%$ & $91 \%$ & $58 \%$ & $47 \%$ \\
& $26 \%$ & $49 \%$ & $41 \%$ & $81 \%$ & $52 \%$ & $43 \%$ \\
\hline
\end{tabular}

times. As expected, the RVF decreases when the oven temperature increases (e.g. from $34 \%$ to $16 \%$ for $40 \mathrm{~nm}$ particles, respectively, from $100^{\circ} \mathrm{C}$ to $250^{\circ} \mathrm{C}$ at reaction time $5 \mathrm{~h}$ ).

Figure 2 shows that at $t=5 \mathrm{~h}$ and $9.5 \mathrm{~h}$, the RVF is lower than $35 \%$. At higher reaction times, the RVF increases drastically (e.g. $81 \%$ for $50 \mathrm{~nm}$ particles at $100^{\circ} \mathrm{C}$ and $43 \%$ at $250^{\circ} \mathrm{C}$ at $t=22 \mathrm{~h}$ ), indicating that the SOA formed by in-cloud photooxidation are mostly volatile at $100^{\circ} \mathrm{C}$ at the beginning of the reaction, but become more and more refractory with increasing oxidation time. For reaction times up to $9.5 \mathrm{~h}$, the consistency of the RVF between the $40 \mathrm{~nm}$ and $50 \mathrm{~nm}$ particles shows that, at a given temperature, the volatilized fraction is not dependent on the particle size, which indicates that the volatilization may have reached equilibrium within the VHTDMA oven, i.e. the residence time in the oven is sufficient. However, as the reaction time increases, the discrepancy between the RVF of $40 \mathrm{~nm}$ particles and the RVF of $50 \mathrm{~nm}$ particle becomes more important, indicating that volatilization kinetics may play a role for these less volatile SOA, and that the aerosol may not have been evaporated to the level of the gas/phase equilibrium corresponding to the temperature of the oven, given the $2 \mathrm{~s}$ residence time. However, the discrepancy is only a few percent, and we will later hypothesize that the RVF does not significantly depend on the original SOA mass. An et al. (2007) measured a RVF of $\approx 55 \%$ for a $100 \mathrm{~nm}$ particle of SOA formed after $10 \mathrm{~h}$ of reaction between $\alpha$-pinene and $\mathrm{O}_{3}$, with a residence time of $1.8 \mathrm{~s}$ and a temperature of $100^{\circ} \mathrm{C}$. Our results show a more volatile SOA for similar residence time and reaction time (RVF of around 20\%). In their study, no clear relationship was found between the SOA formed after $4 \mathrm{~h}$ of reaction and the SOA formed after $10 \mathrm{~h}$ of reactions. Here, we see evidence of a significant change with reaction advancement, which has also been detected by Kalberer et al. (2004) in their study of gas-phase photooxidation of trimethylbenzenes. An increase of the concentration of high molecular weight multifunctional products associated to multiple isomers and oligomers have been detected as a function of reaction time by El Haddad et al. (2009) in the aqueous phase, and may be responsible for the volatility change of the droplet residual particle. An increase in $100^{\circ} \mathrm{C}$ non-volatile particle fraction has been attributed in the literature to poly-

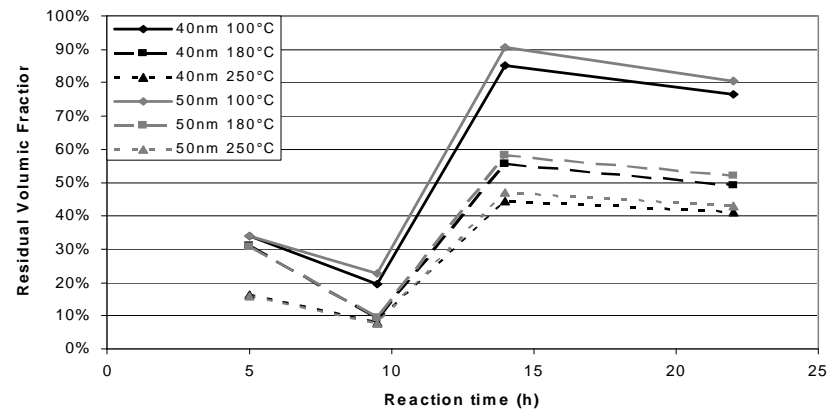

Fig. 2. Residual Volumic Fraction (RVF) of the SOA obtained after different aqueous-phase reaction times, using VTDMA oven temperatures of 100,180 and $250^{\circ} \mathrm{C}$.

mer formation (Kalberer et al., 2004; Paulsen et al., 2006). The VTDMA results by Kalberer et al. (2004) revealed a polymerisation rate of $2.6 \% \mathrm{hr}^{-1}$ (in volume). Here we found that the increase of the $100^{\circ} \mathrm{C}$-refractory fraction is not linear, and that after $9.5 \mathrm{~h}$ of reaction, it represents $5.7-6.3 \%$ (in volume) per hour. If all refractory material was attributed to oligomerization, our results would show a saturation of the oligomerization after $14 \mathrm{~h}$ of reaction, and a takeover by non-oligomerizing components.

\subsubsection{Hygroscopicity studies}

The HTDMA measurements at $90 \%$ RH performed for 40 and $50 \mathrm{~nm}$ pure SOA formed upon water evaporation after different reaction times have each shown a monomodal humidified aerosol size distribution. This behaviour suggests that the SOA is an internal mixture. The pure SOA were moderately hygroscopic, with hygroscopic growth factors varying between 1.34 and 1.43 (Table 3). These values are comparable to those reported by Prenni et al. (2003) for oxalic acid $(\mathrm{HGF}=1.43)$. In the gas-phase, SOA formed from photooxidation usually show lower hygroscopic growth factors. Varutbangkul et al. (2006) measured lower HGF for SOA formed in simulation chambers during the gas-phase photooxidation or ozonolysis of cycloalkenes $(1.14<\mathrm{HGF}<1.22)$, monoterpenes $(1.10<\mathrm{HGF}<1.16)$ and sesquiterpenes $(1.03<\mathrm{HGF}<1.08)$. Vesna et al. (2008) also 
Table 3. GF values for HTDMA, VTDMA and VHTDMA and calculated hygroscopicity of the $250^{\circ} \mathrm{C}$ volatile volumic fraction (VVF) (see text in Sect. 3.1.3. for details on the calculation method) of "pure SOA" formed after different reaction times for $40 \mathrm{~nm}$ particles. RH=90.8\% and oven temperature $\approx 250^{\circ} \mathrm{C}$. The uncertainty is calculated as the standard deviation over the different scans performed for a given reaction time.

\begin{tabular}{lrrrrr}
\hline \multicolumn{2}{l}{ Diameter $\left(\mathrm{Dp}_{0} 0\right)$} & \multicolumn{4}{c}{$40 \mathrm{~nm}$} \\
\hline \multicolumn{1}{l}{ Settings } & H GF & V GF & VH GF & H GF of VVF \\
\hline \multirow{2}{*}{ Time } & $5.5 \mathrm{~h}$ & $1.43 \pm 0.02$ & $0.55 \pm 0.01$ & $1.52 \pm 0.04$ & 1.41 \\
reaction & $14 \mathrm{~h}$ & $1.34 \pm 0.00$ & $0.43 \pm 0.00$ & $1.49 \pm 0.02$ & 1.39 \\
& $22 \mathrm{~h}$ & $1.41 \pm 0.00$ & $0.76 \pm 0.00$ & $1.32 \pm 0.01$ & 1.36 \\
& & & & & 1.44 \\
\hline
\end{tabular}

measured lower HGF during the ozonolysis of unsaturated fatty acids $(1.03<\mathrm{HGF}<1.09)$. This difference can be explained in two ways: i) the influence of the chemical structure of the precursor VOC; ii) the formation mechanism of the SOA. (i) Compared to methacrolein, higher-molecular weight hydrocarbon precursors tend to produce larger oxidation and less hygroscopic products (Varutbangkul et al., 2006). ii) The higher hygroscopicity of the SOA obtained here could be associated with its formation mechanisms, as differences exist between aqueous phase and gas phase reaction products. Vesna et al. (2007) showed in laboratory experiments that during the heterogeneous ozonolysis of arachidonic acid particles, hygroscopic changes induced by humidity are accompanied by about a doubling of the ratio of carboxylic acid protons to aliphatic protons. The authors suggest that, under humid conditions, the reaction of water with the Criegee intermediates might open a pathway for the formation of smaller acids that lead to more significant changes in hygroscopicity. Chen et al. (2008) have suggested from an aqueous-phase ozonolysis study of methyl vinyl ketone and methacrolein that pathways leading to hydrogen peroxide via hydroxy-hydroperoxides might be important. The decomposition of the hydroperoxides may also lead to acids. Therefore, humidity might have a significant effect on the yield of hygroscopic products. It has already been reported that the aqueous phase processes yield higher amounts of carboxylic acids than the gas phase oxidation (Blando and Turpin, 2000; Monod et al., 2000). Sorooshian et al. (2007) found that the ratio of oxalic acid-to-sulfate was significantly increased above clouds, and attributed this increase to aqueous-phase reactions. This is also supported, in the samples used in the present study, by the MS/MS analysis of the aqueous phase products that reveals the presence of multifunctional carboxylic acids (El Haddad et al., 2009). These products are believed to be hydrophilic and hence increase the hygroscopicity of the SOA, compared to gas phase oxidation products. In this study, the HGF seems to experience a slight decrease from 1.43 to 1.36 with reaction time until $14 \mathrm{~h}$ of reaction, and then an increase back to 1.41. The oligomerization is expected to decrease the parti-

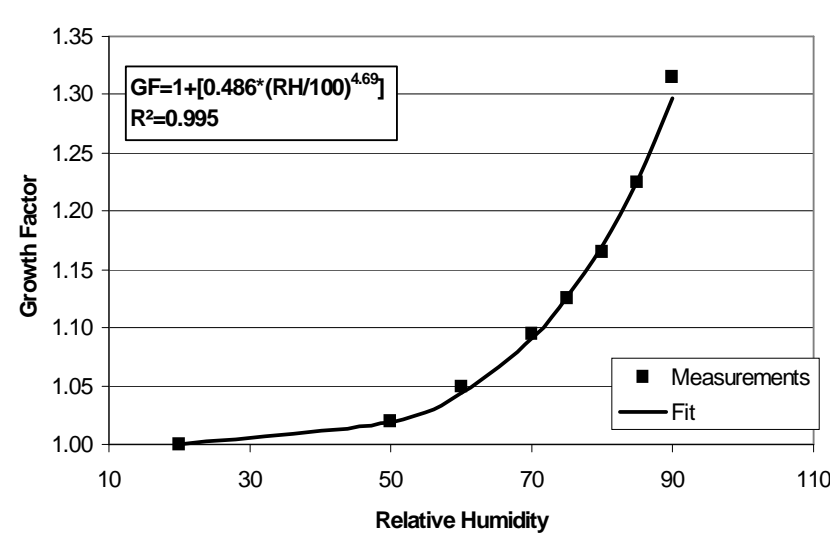

Fig. 3. Humidogram of Pure SOA particles at $50 \mathrm{~nm}$ and for a reaction time of $t=14 \mathrm{~h}$.

cle hygroscopicity with time, which is in agreement with the volatility study for the first $14 \mathrm{~h}$. After $14 \mathrm{~h}$ of reaction, the formation of non-oligomerizing compounds would slightly enhance the HGF again. Varutbangkul et al. (2006) have also found a decreasing hygroscopicity with reaction time for SOA formed by the photooxidation of sesquiterpene, attributed to oligomer formation. Our results seem to agree with their postulate according to which the oligomerization is competing with the formation of more hygroscopic polar oxidized species.

At the reaction time $14 \mathrm{~h}$, the $\mathrm{RH}$ in the HTDMA humidification chamber was ramped up from $50 \%$ to $90 \%$, in order to better describe the SOA formed in the aqueous phase. The resulting hygroscopic growth curve, presented in Fig. 3, does not exhibit a deliquescence behaviour, which is characteristic of organic aerosol particles (Dick et al., 2000; Rudich et al., 2007).

The experimental data were fitted using the empirical functional form reported previously by Varutbangkul et al. (2006) for SOA formed from several VOC precursors in the gas phase: 
$\mathrm{GF}=1+\left[\left(1-\frac{\mathrm{RH}}{100}\right)^{-A} \times B\left(\frac{\mathrm{RH}}{100}\right)^{C}\right]$

Where, RH is the relative humidity, and $A, B$, and $C$ are positive empirical parameters. The fit parameter $A$, more representative of the inorganic fraction (Swietlicki et al., 2000) was not significantly different from 0 , and the second functional term ( $B=0.486 ; C=4.69)$, frequently used to model dicarboxylic acids (Wise et al., 2003) was sufficient to satisfactorily represent our data $\left(R^{2}=0.995\right.$; Fig. 3$)$. This suggests that the hygroscopic behaviour of the obtained SOA is similar to photooxidized biogenic organics reported by Varutbangkul et al. (2006). This parameterization allows for the computation of the SOA at any given RH. Inorganic salts usually exhibit a deliquescence point below which the aerosol stays in the dry state. A SOA coating such as the one which would be formed through in-cloud processes of methacrolein would, hence, allow water uptake at lower RHs than the pure inorganic portion alone, modifying among other parameters, its optical properties and interactions with other trace gases.

\subsubsection{Volatility-hygroscopicity combined studies}

The hygroscopicity at $\mathrm{RH}=90 \%$ of the refractory core after volatilization at $250^{\circ} \mathrm{C}$ (VHGF) were calculated according to Eq. (4) and are reported in Table 3. It can be observed that the hygroscopic properties of the $250^{\circ} \mathrm{C}$-refractory fraction significantly changes with the reaction time contrarily to the HGF of the whole "pure SOA" aerosol, as it becomes less hygroscopic. The VHGF varies from $1.52(t=5 \mathrm{~h})$ to $1.36(t=22 \mathrm{~h})$. It should be emphasised here that for a given particle composition, smaller particles would tend to show smaller HGF than larger particles (Kelvin effect). Hence, the larger HGF observed for the small refractory fraction at $5 \mathrm{~h}$ $(\mathrm{RVF}=16 \%)$ compared to the ones at $22 \mathrm{~h}(\mathrm{RVF}=42 \%)$ can not be due to a change of size, and this fraction, presumably representative of the highest molecular weight compounds, become less hygroscopic with the reaction time. This behaviour indicates that the decrease in hygroscopicity with time is attributed to both the formation of more refractory material, and a decrease of hygroscopicity of this refractory fraction.

From the HGF of the total "pure SOA" aerosol volume and of the refractory fraction, the HGF of the volatile volumic fraction (VVF, calculated as (1-RVF), Table 3) has been calculated using the ZSR (Zdanovskii-Stokes-Robinson) theory (Eq. 6), according to which the water uptake of a mixture is the sum (by mass) of the water uptake of each individual component.

$$
\mathrm{GF}=\sqrt[3]{\alpha \cdot \mathrm{HGF}_{\alpha}^{3}+\beta \cdot \mathrm{HGF}_{\beta}^{3}}
$$

Where $\mathrm{HGF}_{\alpha}$ and $\mathrm{HGF}_{\beta}$ are the HGF of the component present in the particle with the respective fraction of alpha and beta. This theory has been used by many authors (Marcolli and al., 2004) with good results. In our case, $\alpha$ and $\beta$ are respectively the $250^{\circ} \mathrm{C}-\mathrm{RVF}$ and $250^{\circ} \mathrm{C}-\mathrm{VVF}$ of the aerosol particles.

One can observe that the $250^{\circ} \mathrm{C}$-volatile fraction does not vary much with time (from 1.36 to 1.41 , Table 3 ). Before $t=9.5 \mathrm{~h}$, the $250^{\circ} \mathrm{C}$-refractory fraction is significantly more hygroscopic than the volatile fraction, but because it represents only 8 to $16 \%$ of the total particle volume (Table 2 ), the effect is not detected on the total particle hygroscopicity. During the gas phase ozonolysis of sesquiterpenecaryophyllene, Asa-Awuku et al. (2009) found on the contrary that the hygroscopic fraction of the SOA is volatile. This is another difference which might be due to aqueous phase SOA formation compared to gas-phase reactions. At reaction times higher than $9.5 \mathrm{~h}$, the $250^{\circ} \mathrm{C}$-refractory volume increases (Table 2), and in parallel, its hygroscopicity decreases. As a consequence, the hygroscopicity of the total volume of SOA particles does not evolve linearly with the reaction time.

The goal of next section is to observe the effect of the production of such a moderately hygroscopic SOA in a droplet which would originally contain an hygroscopic salt (sea salt).

\section{2 $\mathrm{SOA}+\mathrm{NaCl}$ experiments}

\subsubsection{Volatility studies}

The volatility scans are all mono-modal, indicating that SOA and the sea salt $(\mathrm{NaCl})$ are internally mixed aerosol. Table 4 shows the refractory fractions of the mixture $\mathrm{SOA}$ and $\mathrm{NaCl}$ at different temperatures and reaction times. As expected, the mixed particles are much more refractory than the pure SOA particles, due to the presence of sea salt. The refractory fraction does not linearly evolves with the reaction time, because it is the result of the combination between an increase of the $\mathrm{SOA}$ mass fraction in the $\mathrm{SOA}+\mathrm{NaCl}$ mixture (increasing volatility of the total mixture), and a decreasing volatility of this SOA fraction.

From the volatilized volume measured during the pure SOA experiments, and the volatilized volume reported in Table 4 , we can calculate the volumic fraction of SOA ( $\left.\chi_{\mathrm{SOA}}\right)$ mixed with $\mathrm{NaCl}$ for each reaction time according to Eq. (7):

$\chi_{\mathrm{SOA}}=\frac{\left.\mathrm{VVF}_{(\mathrm{NaCl}}+\mathrm{SOA}\right)}{\mathrm{VVF}_{(\mathrm{SOA})}}$

Equation (7) is valid only if the organic solutions (sampled during the aqueous-phase photooxidation of methacrolein) are not influenced by the presence of an inorganic salt such as $\mathrm{NaCl}$. This should be the case since the $\mathrm{NaCl}$ salt was added to the aqueous solution after the reaction had taken place. This hypothesis will be confirmed hereafter using the 
Table 4. Residual Volumic Fraction (RVF) of "SOA+NaCl" aerosol formed after different reaction times, after heating in VTDMA at 100, 180 and $250^{\circ} \mathrm{C}$. The diameter of the incident particles (selected in the first DMA) is 40 or $50 \mathrm{~nm}$. The values of RVF indicated are obtained starting from the average of two measurements. ND stands for Not Detected.

\begin{tabular}{lrrrrrrr}
\hline \multicolumn{2}{l}{ Diameter $\left(\mathrm{Dp}_{0} 0\right)$} & \multicolumn{3}{c}{$40 \mathrm{~nm}$} & \multicolumn{3}{c}{$50 \mathrm{~nm}$} \\
\hline \multicolumn{2}{l}{ Temperature $\left({ }^{\circ} \mathrm{C}\right)$} & $100^{\circ} \mathrm{C}$ & $180^{\circ} \mathrm{C}$ & $250^{\circ} \mathrm{C}$ & $100^{\circ} \mathrm{C}$ & $180^{\circ} \mathrm{C}$ & $250^{\circ} \mathrm{C}$ \\
\hline \multirow{3}{*}{ Time } & $5 \mathrm{~h}$ & $\mathrm{ND}$ & $\mathrm{ND}$ & $\mathrm{ND}$ & $\mathrm{ND}$ & $\mathrm{ND}$ & $\mathrm{ND}$ \\
reaction & $9.5 \mathrm{~h}$ & $90 \%$ & $85 \%$ & $87 \%$ & $94 \%$ & $89 \%$ & $88 \%$ \\
& $14 \mathrm{~h}$ & $92 \%$ & $87 \%$ & $87 \%$ & $94 \%$ & $91 \%$ & $89 \%$ \\
& $22 \mathrm{~h}$ & $90 \%$ & $83 \%$ & $82 \%$ & $95 \%$ & $89 \%$ & $86 \%$ \\
\hline
\end{tabular}

Table 5. SOA volume fraction for each reaction time and each volatilization temperature, calculated according to Eq. (7). The approximated mass fraction was calculated using a density of 1.4 for SOA.

\begin{tabular}{|c|c|c|c|c|c|c|c|c|c|}
\hline \multicolumn{2}{|c|}{ Diameter $\left(\mathrm{Dp}_{0} 0\right)$} & \multicolumn{3}{|c|}{$40 \mathrm{~nm}$} & \multicolumn{3}{|c|}{$50 \mathrm{~nm}$} & \multirow{2}{*}{$\begin{array}{r}\text { Mean SOA } \\
\text { volume } \\
\text { Fraction }\left(\chi_{\mathrm{SOA}}\right)\end{array}$} & \multirow{2}{*}{$\begin{array}{r}\text { SOA mass } \\
\text { production } \\
\left(\varepsilon_{\mathrm{SOA}} \times 100 \mathrm{mgL}^{-1}\right)\end{array}$} \\
\hline Tempera & $\left({ }^{\circ} \mathrm{C}\right)$ & $100^{\circ} \mathrm{C}$ & $180^{\circ} \mathrm{C}$ & $250^{\circ} \mathrm{C}$ & $100^{\circ} \mathrm{C}$ & $180^{\circ} \mathrm{C}$ & $250^{\circ} \mathrm{C}$ & & \\
\hline \multirow{3}{*}{$\begin{array}{l}\text { Time } \\
\text { reaction }\end{array}$} & $9.5 \mathrm{~h}$ & $12 \%$ & $16 \%$ & $14 \%$ & $8 \%$ & $12 \%$ & $13 \%$ & $13 \pm 3 \%$ & $19 \pm 4$ \\
\hline & $14 \mathrm{~h}$ & $53 \%$ & $30 \%$ & $23 \%$ & $67 \%$ & $21 \%$ & $21 \%$ & $36 \pm 18 \%$ & $48 \pm 24$ \\
\hline & $22 \mathrm{~h}$ & $42 \%$ & $33 \%$ & $31 \%$ & $26 \%$ & $23 \%$ & $25 \%$ & $30 \pm 6 \%$ & $41 \pm 9$ \\
\hline
\end{tabular}

hygroscopicity measurements. The mass fraction of SOA $\left(\varepsilon_{\mathrm{SOA}}\right)$ can be calculated by:

$\varepsilon \mathrm{SOA}=\chi_{\mathrm{SOA}} \frac{\rho_{\mathrm{SOA}} * \chi_{\mathrm{SOA}}+\rho_{\mathrm{NaCl}} *\left(1-\chi_{\mathrm{SOA}}\right)}{\rho_{\mathrm{SOA}}}$

Where $\rho_{\mathrm{SOA}}$ is the density of the SOA and $\rho_{\mathrm{NaCl}}$ is the density of $\mathrm{NaCl}\left(2.16 \mathrm{~g} \mathrm{~cm}^{-3}\right)$. A density $1-1.2 \mathrm{~g} \mathrm{~cm}^{-3}$ has often been used for organic particles (Presto et al., 2005; Pathak et al., 2006). Higher values have, however, been recently measured. Varutbangkul et al. (2006) measured a density of 1.3 for monoterpene and oxygenated terpene precursors in seeded experiments and most recently, and a range of 1.41.65 has been proposed for SOA formed from ozonolysis of terpenes (Kostenidou et al., 2007). The density of the SOA produced in our experiment is most likely not constant with time, more oxygenated compounds are expected to have higher densities (Katrib et al., 2006). We chose to estimate the mass fraction of SOA produced in our experiment by using an average density of 1.4. The fraction of SOA in the $\mathrm{SOA}+\mathrm{NaCl}$ mixture should be constant whatever the temperature of volatilization and whatever the particle selected size $(40$ or $50 \mathrm{~nm})$ for each reaction time, assuming that the volatilized fraction is not dependent on the particle size, as demonstrated in Sect. 3.1.1. Table 5 gives six different evaluations of the SOA mass fraction for each reaction time. The results show that, except for the $14 \mathrm{~h}$ reaction time, the variability of the SOA mass fraction calculation is reasonably low within each experiment, which gives some confidence on this calculation.
Because the amount of $\mathrm{NaCl}$ dissolved in the liquid sample was $100 \mathrm{mg} \mathrm{L}^{-1}$, we can calculate the mass of SOA produced in the liquid phase (Table 5). The SOA mass production has also been calculated from the SMPS size distribution (El Haddad et al., 2009), and it was found that 14.3 \pm 4.9 , $23.8 \pm 8.1$ and $32.7 \pm 11.1 \mathrm{mg} \mathrm{L}^{-1}$ of SOA were produced, respectively, at $t=9.5 \mathrm{~h}, 14 \mathrm{~h}$ and $22 \mathrm{~h}$. These values, obtained with independent calculation methods, are in good agreement with the ones presented here, within the uncertainties.

\subsubsection{Hygroscopicity studies}

Again, the HTDMA size distributions of the droplet's residual aerosols observed for this set of experiments showed a single mode, confirming that the organic and the inorganic fractions formed an internally mixed aerosol. At reaction time $0 \mathrm{~h}$, the aerosol HGF $(2.35 \pm 0.02$ at $40 \mathrm{~nm}$ and $\mathrm{RH}=90.8 \%$ ) was equal to that of pure $\mathrm{NaCl}$, within the uncertainties of the measurement: the hygroscopic growth of a pure $40 \mathrm{~nm} \mathrm{NaCl}$ particle is 2.33 at $90.8 \%$ (Hameri et al., 2001).

With the reaction advancement, the HGF decreases significantly, as the less-hygroscopic organic fraction increases (Table 6). Using the SOA mass production (Table 5), we can calculate the expected hygroscopic growth by combining the HGF of "pure SOA" measured in the previous section, and the HGF of pure $\mathrm{NaCl}$ measured at the beginning of the experiment (average 2.35) with the ZSR relationship (Eq. 6). We find a very good agreement between the calculated and 
measured HGF, except for the reaction time of $14 \mathrm{~h}$ (Table 6). These results indicate that the hygroscopicity of the SOA formed by nebulization of solutions after aqueous-phase photooxidation is reproducible when a salt is present in the liquid phase. As a consequence, we can conclude that the salt does not interact with the polar compounds that might be produced as SOA. These results also strengthen our evaluation of the SOA yields.

\section{Summary and conclusions}

The physical properties of SOA (hygroscopicity, volatility) produced from the nebulization of solutions after aqueousphase photooxidation of methacrolein was studied for the first time to our knowledge. Methacrolein was chosen because it is one of the major reaction products of isoprene in the atmosphere, and it has been observed in natural cloud waters (van Pinxteren et al., 2005). The hygroscopic and volatility properties of the obtained SOA were experimentally studied in laboratory, by using the VHTDMA technique. The SOA is $80 \% 100^{\circ} \mathrm{C}$-volatile after $5 \mathrm{~h}$ of reaction, but the volatility drastically decreases as the reaction time increases, and after $22 \mathrm{~h}$ of reaction, the SOA is only $20 \% 100^{\circ} \mathrm{C}$-volatile. The SOA formed through the nebulization of solutions after aqueous-phase photooxidation of methacrolein is, hence, more volatile than the ones formed through gas-phase photooxidation of terpenes after a few hours of reactions. This difference can be explained by i) the difference of the chemical structure of the precursor VOC and ii) the different formation pathways of the SOA. Ageing has a significant effect on the volatilization properties, in agreement with ageing of some gas-phase terpene photooxidation products (Kalberer et al., 2004). Oligomeres have been observed to be formed during aqueous-phase glycoaldehyde oxidation (Perri et al., 2009). Oligomerization is suspected to form $100^{\circ} \mathrm{C}$-refractory compounds which can explain our results. We observed that the oligomerization process is in competition with the formation of other nonoligomerizing compounds, detected as unidentified higher molecular weight multifunctional products by El Haddad et al. (2009). The same volatility properties characterize the SOA formed from the nebulization of the same solutions where $\mathrm{NaCl}$ was added, indicating a good reproducibility of our results. The HGF of the SOA produced from the nebulization of solutions after liquid-phase photooxidation of methacrolein is $1.34-1.43$, which is slightly higher than the HGF of SOA formed from the gas-phase photooxidation of terpenes. This result can be due to the presence of hygroscopic products such as oxalic acid or dihydroxymethacrylic acid (El Haddad et al., 2009), and it confirms the volatility results. Before Oligomerization took place (at $t=5 \mathrm{~h}$ ), we observed that the hygroscopicity of the $250^{\circ} \mathrm{C}$ refractory fraction was higher than the hygroscocpicity of the volatile fraction (1.52 vs. 1.41, respectively). Meyer et
Table 6. HGF of particles produced from the nebulization of a mixture of $100 \mathrm{ml}$ of $\mathrm{NaCl}$ and the $\mathrm{OH}$-oxidation product of methacrolein in the liquid phase, calculated from the ZSR theory and measured at $\mathrm{RH}=90.8 \%$.

\begin{tabular}{lrrr}
\hline $\begin{array}{l}\text { Diameter } \\
\left(\mathrm{Dp}_{0}\right)\end{array}$ & $\begin{array}{r}40 \mathrm{~nm} \\
(38 \mathrm{~nm})\end{array}$ & HGF of "SOA+NaCl" aerosol \\
\cline { 3 - 4 } & & Calculated HGF & Measured HGF \\
\hline & $0 \mathrm{~h}$ & 2.33 & $2.35 \pm 0.02$ \\
Reaction & $5 \mathrm{~h}$ & $\mathrm{ND}$ & $\mathrm{ND}$ \\
Time & $9.5 \mathrm{~h}$ & 2.20 & $2.23 \pm 0.03$ \\
& $14 \mathrm{~h}$ & 2.04 & $2.18 \pm 0.01$ \\
& $22 \mathrm{~h}$ & 2.09 & $2.10 \pm 0.01$ \\
\hline
\end{tabular}

al. (2009) and Asa-Awuku et al. (2009) had observed with gas phase SOA formation that more volatile compounds appear to be more hygroscopic. The hygroscopic properties of the whole cloud droplet residuals, however, do not evolve linearly with the reaction time, as it is the result of the combination between an increase of the SOA $250^{\circ} \mathrm{C}$-refractory fraction, and a decreasing hygroscopicity of this refractory fraction. The hygroscopic properties of its $250^{\circ} \mathrm{C}$-refractory fraction (presumably representative of the highest molecular weigh compounds), evolved from moderately hygroscopic (HGF of 1.52) to less hygroscopic (HGF of 1.36). This result is in agreement with the oligomerization process which is expected to form less hygroscopic compounds. It can also be compared to other SOA ageing experiments. Perri et al. (2009) observe the production of low volatility organic acids and oligmers via aqueous photo-oxidation.

The hygroscopic properties of SOA produced from methacrolein aqueous phase oxidation were additionally confirmed when the nebulization was performed with the same aqueous solutions where $\mathrm{NaCl}$ was added. We have shown, for the first time, that this SOA had volatility and hygroscopic properties which were significantly different from SOA formed through gas-phase photooxidation processes.

By using its volatility properties, the mass of SOA could be evaluated relatively to the added $\mathrm{NaCl}$. The results showed that $19 \pm 6 \mathrm{ng} \mathrm{L}^{-1}$ and $41 \pm 9 \mathrm{ng} \mathrm{L}^{-1}$ of SOA were produced after $9.5 \mathrm{~h}$ of reaction and after $22 \mathrm{~h}$, respectively. These results are in good agreement with those of El Haddad et al. (2009). Hence, our results have experimentally confirmed that cloud processes of methacrolein, one of the major products of isoprene, can produce significant amounts of SOA. Because more and more SOA is formed as the reaction time increases, the impact of methacrolein photooxidation on the residual particles becomes more and more significant and, hence, can modify the properties of an initially hygroscopic particle. $\mathrm{NaCl}$ seeded aerosols experience, at $90 \% \mathrm{RH}$, an hygroscocpic growth fator change of $6 \%$ after $9.5 \mathrm{~h}$ of reaction. We expect that the impact of the formation of a moderately hygroscopic SOA, such as the one which was evident in this experiment (HGF of 1.43), would 
be higher in case it is due to a coating over a hydrophobic seed instead of a $\mathrm{NaCl}$ seed. But more importantly, the lack of a deliquescence point, which is characteristic of SOA, involves that a coated $\mathrm{NaCl}$ particle would take up water at lower $\mathrm{RH}$ than an un-coated particle. SOA, produced through in-cloud processes, can play an important role in extending the range of RHs over which particle-bound water influences aerosol properties, such as density, light scattering, or refractive index and heterogeneous chemical reactivity. Additional effects, such as a lower deliquescent RH recently observed by Meyer et al. (2009) might increase the impact of SOA on the inorganic fraction of particles. The combination of the knowledge of SOA aqueous-phase yields and its physical properties should be helpful to better assess the global estimation of SOA atmospheric impacts.

Edited by: V. F. McNeill

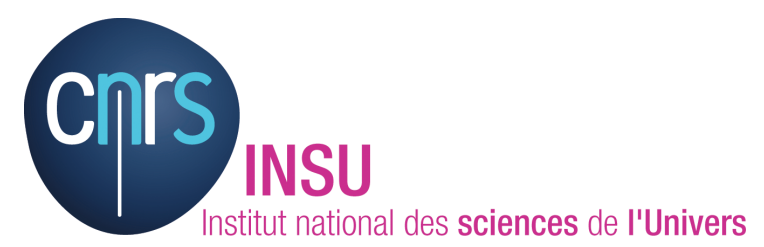

The publication of this article is financed by CNRS-INSU.

\section{References}

Altieri, K. E., Seitzinger, S. P., Carlton, A. G., Turpin, B. J., Klein, G. C., and Marshall, A. G.: Oligomers formed through in-cloud methylglyoxal reactions: Chemical composition, properties, and mechanisms investigated by ultra-high resolution FT-ICR mass spectrometry, Atmos. Environ., 42, 1476-1490, 2008.

An, W. J., Pathak, R. K., and Pandis, S. N.: Aerosol volatility measurement using an improved thermodenuder: Application to secondary organic aerosol, Aerosol Sci., 38, 305-314, 2007.

Asa-Awuku, A., Engelhart, G. J., Lee, B. H., Pandis, S. N., and Nenes, A.: Relating CCN activity, volatility, and droplet growth kinetics of $\beta$-caryophyllene secondary organic aerosol, Atmos. Chem. Phys., 9, 795-812, 2009,

http://www.atmos-chem-phys.net/9/795/2009/.

Ansari, A. S. and Pandis, S. N.: Prediction of multicomponent inorganic atmospheric aerosol behavior, Atmos. Environ., 33(5), 745-757, 1999.

Bilde, M. and Svenningsson., B.: CCN activation of slightly soluble organics: the importance of small amounts of inorganic salt and particle phase, Tellus, 56B, 123-134, 2004.

Blando, J. D. and Turpin, B. J.: Secondary organic aerosol formation in cloud and fog droplets: a literature evaluation of plausibility, Atmos. Environ., 34, 1623-1632, 2000.

Clegg, S. L. and Seinfeld, J. H.: Thermodynamic models of aqueous solution containing inorganic electrolytes and dicarboxylic acids at $298.15 \mathrm{~K}$. 1. The acids as nondissociating components, J. Phys. Chem. A, 110, 5692-5717, 2006.

Chan, M. N. and Chan, C. K.: Hygroscopicity of a model humiclike substance and its mixture with sodium chloride, Abstracts of the European Aerosol Conference, 2003.
Chen, Z. M., Wang, H. L., Zhu, L. H., Wang, C. X., Jie, C. Y., and Hua, W.: Aqueous-phase ozonolysis of methacrolein and methyl vinyl ketone: a potentially important source of atmospheric aqueous oxidants, Atmos. Chem. Phys., 8, 2255-2265, 2008, http://www.atmos-chem-phys.net/8/2255/2008/.

Colberg, C. A., Luo, B. P., Wernli, H., Koop, T., and Peter, Th.: A novel model to predict the physical state of atmospheric $\mathrm{H}_{2} \mathrm{SO}_{4} / \mathrm{NH}_{3} / \mathrm{H}_{2} \mathrm{O}$ aerosol particles, Atmos. Chem. Phys., 3, 909-924, 2003,

http://www.atmos-chem-phys.net/3/909/2003/.

Crumeyrolle, S., Gomes, L., Tulet, P., Matsuki, A., Schwarzenboeck, A., and Crahan, K.: Increase of the aerosol hygroscopicity by cloud processing in a mesoscale convective system: a case study from the AMMA campaign, Atmos. Chem. Phys., 8, 6907-6924, 2008, http://www.atmos-chem-phys.net/8/6907/2008/.

Decesari, S., Facchini, M. C., Fuzzi, S., and Tagliavini, E.: Characterization of water-soluble organic compounds in the atmospheric aerosol: A new approach, J. Geophys. Res., 105, 14811489, 2000.

Dick, W. D., Saxena, P., and McMurry, P. H.: Estimation of water uptake by organic compounds in submicron aerosols measured during the Southeastern Aerosol and Visibility Study, J. Geophys. Res.-Atmos., 105(D1), 1471-1479, 2000.

Duplissy, J., Gysel, M., Sjogren, S., Meyer, N., Good, N., Kammermann, L., Michaud, V., Weigel, R., Martins dos Santos, S., Gruening, C., Villani, P., Laj, P., Sellegri, K., Metzger, A., McFiggans, G. B., Wehrle, G., Richter, R., Dommen, J., Ristovski, Z., Baltensperger, U., and Weingartner, E.: Intercomparison study of six HTDMAs: results and general recommendations for HTDMA operation, Atmos. Meas. Tech. Discuss., 1, 127168,2008 ,

http://www.atmos-meas-tech-discuss.net/1/127/2008/.

El Haddad, I., Liu, Yao, Nieto-Gligorovski, L., Michaud, V., Temime-Roussel, B., Quivet, E., Marchand, N., Sellegri, K., and Monod, A.: In-cloud processes of methacrolein under simulated conditions - Part 2: Formation of secondary organic aerosol, Atmos. Chem. Phys., 9, 5107-5117, 2009, http://www.atmos-chem-phys.net/9/5107/2009/.

Gelencser, A. and Varga, Z.: Evaluation of the atmospheric significance of multiphase reactions in atmospheric secondary organic aerosol formation, Atmos. Chem. Phys., 5, 2823-2831, 2005, http://www.atmos-chem-phys.net/5/2823/2005/.

Hänel, G.: The properties of atmospheric aerosol as function of the relative humidity at the thermodynamic equilibrium with the surrounding moist air, Adv. Geophys., 19, 74-183, 1976.

Hewitt, G. W.: The charging of small particles for electrostatic precipitation, AIEE Transactions, 76, 300-306, 1957.

IPCC: Climate change: The scientific basis, Cambridge University Press, New York, 2001.

Jennings, S. G. and O'Dowd, C. D.: Volatility of aerosol at Mace Head, on the west coast of Ireland, J. Geophys. Res., 95(D9), 13937-13948, 1990.

Johnson, G. R., Ristovski, Z. D., D’Anna, B., et al.: Hygroscopic behavior of partially volatilized coastal marine aerosols using the volatilization and humidification tandem differential mobility analyzer technique, J. Geophys. Res., 110(D20), D20203, doi:20210.21029/22004JD005657, 2005.

Kostenidou, E., Pathak, R. K. and Pandis, S. N.: An Algorithm for 
the Calculation of Secondary Organic Aerosol Density Combining AMS and SMPS data, Aerosol Sci. Technol., 41(11), 10021010, 2007.

Lee, W., Baasandorj, M., Stevens, P. S., and Hites, R. A.: Monitoring $\mathrm{OH}-$ Initiated Oxidation Kinetics of Isoprene and Its Products Using Online Mass Spectrometry, Environ. Sci. Technol., 39, 1030-1036, 2005.

Levin, Z., Ganor, E., and Gladstein, V.: The effects of desert particles coated with sulfate on rain formation in the eastern mediterranean, J. Appl. Meteorol., 35, 1511-1523, 1996.

Liu, Yao, El Haddad, I., Scarfogliero, M., Nieto-Gligorovski, L., Temime-Roussel, B., Quivet, E., Marchand, N., PicquetVarrault, B., and Monod, A.: In-cloud processes of methacrolein under simulated conditions - Part 1: Aqueous phase photooxidation, Atmos. Chem. Phys., 9, 5093-5105, 2009, http://www.atmos-chem-phys.net/9/5093/2009/.

Liu, B. Y. H., Pui, D. Y. H., Whitby, K. T., Kittleson, D. B., Kousaka, V., and McKenzie, R. L.: Aerosol Mobility Chromatograph - New Detector for Sulfuric-Acid Aerosols, Atmos. Environ., 12, 99-104, 1978.

Kalberer, M., Paulsen, D., Sax, M., Steinbacher, M., Dommen, J., Prevot, A. S. H., Fisseha, R., Weingartner, E., Frankevich, V., Zenobi, R., and Baltensperger, U.: Identification of polymers as major components of atmospheric organic aerosols, Science, 303, 1659-1662, 2004.

Kanakidou, M., Seinfeld, J. H., Pandis, S. N., Barnes, I., Dentener, F. J., Facchini, M. C., Van Dingenen, R., Ervens, B., Nenes, A., Nielsen, C. J., Swietlicki, E., Putaud, J. P., Balkanski, Y., Fuzzi, S., Horth, J., Moortgat, G. K., Winterhalter, R., Myhre, C. E. L., Tsigaridis, K., Vignati, E., Stephanou, E. G., and Wilson, J.: Organic aerosol and global climate modelling: a review, Atmos. Chem. Phys., 5, 1053-1123, 2005,

http://www.atmos-chem-phys.net/5/1053/2005/.

Köhler, H.: The nucleaus in and the growth of atmospheric droplets, T. Faraday Soc., 32, 1152-1161, 1936.

Köhler, H.: The nucleaus in and the growth of atmospheric droplets, T. Faraday Soc., 32, 1152-1161, 1936.

Kreidenweis, S. M., Koehler, K., DeMott, P. J., Prenni, A. J., Carrico, C., and Ervens, B.: Water activity and activation diameters from hygroscopicity data - Part I: Theory and application to inorganic salts, Atmos. Chem. Phys., 5, 1357-1370, 2005, http://www.atmos-chem-phys.net/5/1357/2005/.

Kroll, J. H. and Seinfeld, J. H.: Chemistry of secondary organic aerosol: Formation and evolution of low-volatility organics in the atmosphere, Atmos. Environ., 42, 3593-3624, 2008.

Marcolli, C., Luo, B. P., Peter, T.: Mixing of the organic aerosol fractions: liquids as the thermodynamically stable phases, J. Phys. Chem. A, 108, 2216-2224, 2004.

Meyer, N. K., Duplissy, J., Gysel, M., Metzger, A., Dommen, J., Weingartner, E., Alfarra, M. R., Prevot, A. S. H., Fletcher, C., Good, N., McFiggans, G., Jonsson, Å. M., Hallquist, M., Baltensperger, U., and Ristovski, Z. D.: Analysis of the hygroscopic and volatile properties of ammonium sulphate seeded and unseeded SOA particles, Atmos. Chem. Phys., 9, 721-732, 2009, http://www.atmos-chem-phys.net/9/721/2009/.

Monod, A., Chebbi, A., Durand-Jolibois, R., and Carlier, P.: Oxidation of methanol by hydroxyl radicals in aqueous solution under simulated cloud droplet conditions, Atmos. Environ., 34, 52835294, 2000 .
McFiggans, G., Artaxo, P., Baltensperger, U., Coe, H., Facchini, M. C., Feingold, G., Fuzzi, S., Gysel, M., Laaksonen, A., Lohmann, U., Mentel, T. F., Murphy, D. M., O’Dowd, C. D., Snider, J. R., and Weingartner, E.: The effect of physical and chemical aerosol properties on warm cloud droplet activation, Atmos. Chem. Phys., 6, 2593-2649, 2006,

http://www.atmos-chem-phys.net/6/2593/2006/.

Pathak, K. R., Stanier, O. C., Donahue, M. N., and Pandis, N. S.: Ozonolysis of $\alpha$-pinene at Atmospherically Relevant Concentrations: Temperature Dependence of Aerosol Mass Fractions (Yields), J. Geophys. Res., 112, D03201, doi:10.1029/2006JD007436, 2007.

Paulsen, D., Weingartner E., Alfarra, R., and Baltensperger U.: Volatility measurements of photochemically and nebulizergenerated organic aerosol particles, J. Aerosol Sci., 37(9), 10251051, 2006.

Perri, M. J., Seitzinger, S., and Turpin, B. J.: Secondary organic aerosol production from aqueous photooxidation of glycolaldehyde: Laboratory experiments, Atmos. Environ., 43(8), 14871497, 2009.

Prenni, A. J., DeMott, P. J., and Kreidenweis, S. M.: Water uptake of internally mixed particles containing ammonium sulfate and dicarboxylic acids, Atmos. Environ., 37, 4243-4251, 2003.

Presto, A. A., Huff Hartz, K. E., and Donahue, N. M.: Secondary Organic Production from Terpene Ozonolysis. 1. Effect of Radiation, Environ. Sci. Technol. 39, 7036-7045, 2005.

Ravishankara, A. R.: Heterogeneous and Multiphase Chemistry in the Troposphere, Science, 276, 5315, 1058-1065, doi:10.1126/science.276.5315.1058, 1997.

Rudich, Y., Donahue, N. M., and Mentel, T. F.: Aging of organic aerosol: bridging the gap between laboratory and field studies, Annu. Rev. Phys. Chem., 58, 321-352, 2007.

Shimmo, M., Anttila, P., Hartonen, K., Hÿotyläinen, T., Paatero, J., Kulmala, M., and Riekkola, M.-L.: Identification of organic compounds in atmospheric aerosol particles by online supercritical fluid extraction-liquid chromatography-gas chromatographymass spectrometer, J. Chromat., 151-159, 2004.

Sorooshian, A., Lu, M. L., Brechtel, F. J., Jonsson, H., Feingold, G., Flagan, R. C., and Seinfeld, J. H.: On the source of organic acid aerosol layers above clouds Source, Environ Sci. Technol., 41(13), 4647-4654, 2007.

Swietlicki, E., Hansson, H.-C., Hämeri, K., Svenningsson, B., Massling, A., MCFiggans, G., MCMurry, P. H., Petäjä, T., Tunved, P., Gysel, M., Topping, D., Weingartner, E., Baltensperger, U., Rissler, J., Wiedensholer, A., and Kulmala, M.: Hygroscopic properties of submicrometer atmospheric aerosol particles measured with H-TDMA instruments in various environments - a review, Tellus B, 60, 432-469, doi:10.1111/j.16000889.2008.00350.x, 2008.

Van Pinxteren, D., Plewka, A., Hofmann, D., Müller, K., Kramberger, H., Svrcina, B., Bächmann, K., Jaeschke, W., Mertes, S., Collett Jr., J. L., and Herrmann, H.: Schmuecke hill cap cloud and valley stations aerosol characterisation during FEBUKO (II): Organic compounds, Atmos. Environ., 39, 4305-4320, 2005.

Varutbangkul, V., Brechtel, F. J., Bahreini, R., Ng, N. L., Keywood, M. D., Kroll, J. H., Flagan, R. C., Seinfeld, J. H., Lee, A., and Goldstein, A. H.: Hygroscopicity of secondary organic aerosols formed by oxidation of cycloalkenes, monoterpenes, sesquiterpenes, and related compounds, Atmos. Chem. Phys., 6, 2367- 
2388, 2006,

http://www.atmos-chem-phys.net/6/2367/2006/.

Vesna, O., Sjogren, S., Weingartner, E., Samburova, V., Kalberer, M., Gäggeler, H. W., and Ammann, M.: Changes of fatty acid aerosol hygroscopicity induced by ozonolysis under humid conditions, Atmos. Chem. Phys., 8, 4683-4690, 2008,

http://www.atmos-chem-phys.net/8/4683/2008/.

Villani, P.: Développement, validation et applications d'un système de mesure des propriétés hygroscopiques des particules atmosphériques type VH-TDMA, PhD thesis, 2006.

Villani, P., Picard, D., Michaud V., et al.: Design and Validation of a Volatility Hygroscopic Tandem Differential Mobility Analyzer (VH-TDMA) to Characterize the Relationships Between the Thermal and Hygroscopic Properties of Atmospheric Aerosol Particles, Aerosol Sci. Tech., 42(9), 729-741, 2008.
Villani, P., Sellegri, K., Monier, M., and Laj, P.: Influence of semivolatile species on particle hygroscopic growth, Atmos. Chem. Phys. Discuss., 9, 2021-2047, 2009, http://www.atmos-chem-phys-discuss.net/9/2021/2009/.

Warren, B., Malloy, Q. G. J.,Yee, L. D., et al.: Secondary organic aerosol formation from cyclohexene ozonolysis in the presence of water vapor and dissolved salts, Atmos. Environ., 43(10), 1789-1795, 2009.

Wurzler, S., Reisin, T. G., and Levin, Z.: Modification of mineral dust particles by cloud processing and subsequent effects on drop size distributions, J. Geophys. Res., 105(D4), 4501-4512, 2000. 